\title{
The chemistry between us
}

\section{Highs and lows.}

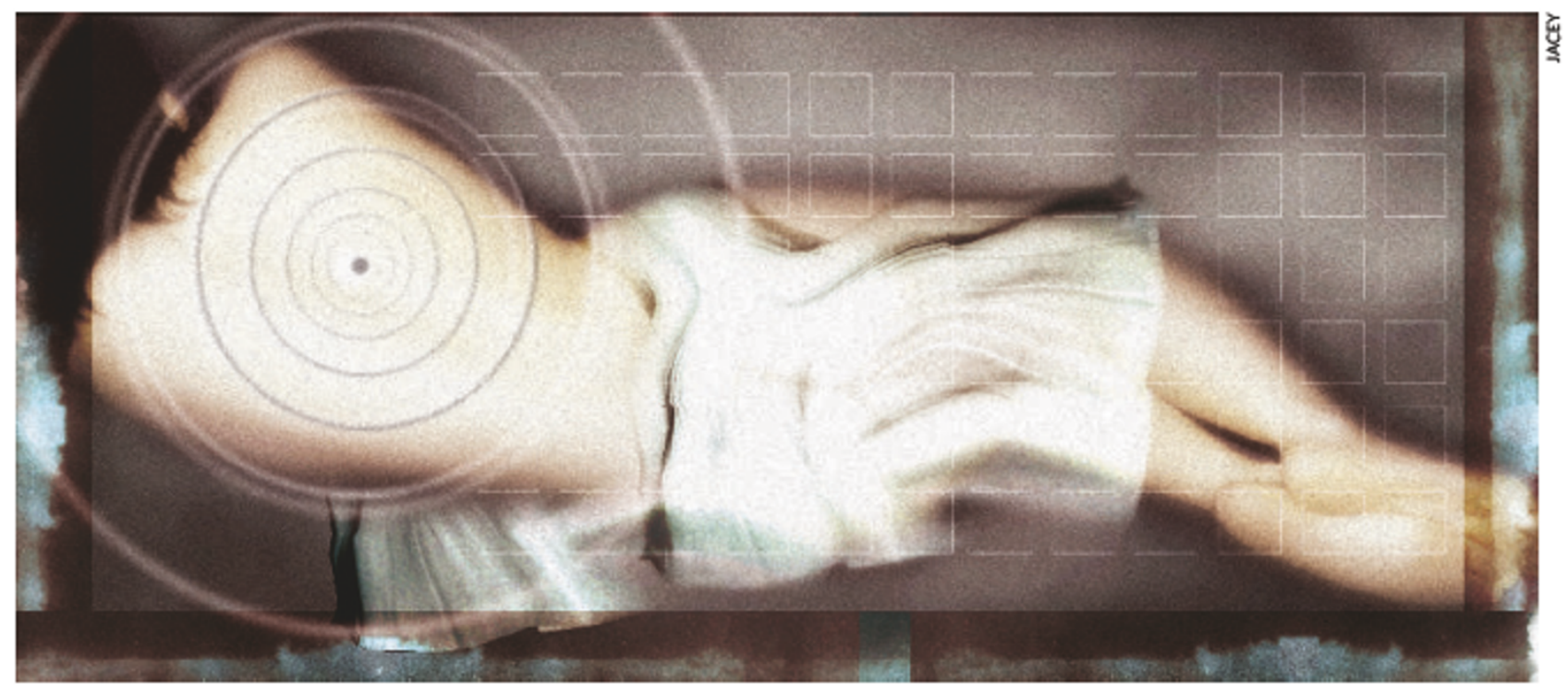

Laura Nelson

I sat on the bed as she lay sleeping. It was the last time.

"How could you not tell me?" I whispered fiercely. She was unaware of my presence; face down on the pillow, hair awry. I was furious with her silence, with her surreptitiousness, with her betrayal. I was furious that I couldn't, any more, be a slave to what she had become.

This girl had innate beauty, like an orchid. With the covers tossed aside, I saw her whole, naked body. Bitterly, I watched her back, flawless and pale. Her hair against her back was a sharp contrast of dark on white. Exquisite hair, naturally aubergine, straight as a taut wire, but soft as fur. I saw her neck underneath it. I'd always loved her neck: slim and tall.

My eyes scanned her neck and shoulders, and there they stopped with the sadness that now hit me, for I knew what was within that exquisite frame, under her skin, now part of her body. And not just her body, but her head too, because the metal box that was implanted in her chest governed the electrical stimulation of her brain, and dictated her moods. How could I have guessed that I would have to compete with an inanimate object - a mesh of wires, a robot - pulsing at regular intervals, triggering the release of natural brain chemicals into her pristine flesh? Was I the one making her happy, or was it her own chemistry, kick-started into action by the fastidious tweaking of a surgeon's fingers? And it had made her happy, she said, since she had got the device a year ago, when we had both been 18 . I remember the two of us, feeling as if we could conquer the world, powerful in our new-found love. I needed nothing else. I was happy. But she - she was not - she needed the metal toy that had become as popular among our contemporaries as the latest computer games. Why, I asked her, as she sat combing my wet, unruly hair on a warm, fresh night by the ocean, when she had me: her girlfriend, her lover? She had felt lost, she replied. Like so many other people, she was complaining that the effects of antidepressant drugs weren't potent or continuous enough. After the implant, she didn't regret it. She felt much better, she said. And there it stayed, in her chest, pumping, through the day, through the night - her brain cells drowning in her own secretions, her temperament soaring. So she said.

Why then, did I begin to see things change for the worse? She became unpredictable, one moment ecstatic, the next moment down. There were no more carefree nights by the ocean. The girl I had known and loved seemed more distant, more distracted. When I broached the subject, daring to suggest the implant might be influencing her personality in ways she hadn't wished for, she scorned me with acerbic words.

Then we found out that other recipients of the device were experiencing similar and more sinister effects. The stories began to surface: hush-hush tales of friends who suddenly developed violent tempers, who turned on their partners and their families, and recoiled into states of despair. Then came rumours of suicides. Initially, reports of friends of friends floated back to us like thick black oil brought in by the tide. Now I had found out that one of our best friends at school had stabbed herself, after the mechanical meddling had finally worked her weary brain to the limit.

She stirred and woke. I must have been frowning because she said: "What's wrong?"

I said: “Gabby killed herself.

"Yes," she said.

"Aren't you worried?"

"What?" she said.

"You might....do the same."

She sighed. "Oh, honeybunny." She paused, as if at my naivety.

Then she said: " I did...try. But I was rescued.

Seeing my dismay, she added: “Baby, don't worry, the pills have all gone. We don't have the pills in the house now. I won't be tempted."

I felt my anger swelling again. I stepped off the bed and stood up. My throat was plugged.

Sweat sprouted on my forehead. "You didn't tell me," I said. My voice was mellow and threatening.

She was crying now. Her body hunched up, her knees were bent into a fetal position; her hair was still sprawled and tears collected in pools above her lower lashes. I sat down on the bed, and gently took her ashen hand; it was hot and clutched. I prized open her fingers. The razor blades that she had been guarding fell like blossom on to the bed, winking at me menacingly in the low light. I laid her hand back down and stood up, trying to avoid her imploring, watery eyes - which would never try to look into my soul like that again - as I turned to walk out of the room.

Laura Nelson is a writer based in London. 